\author{
Loyalitas Kreativitas \\ P-ISSN 2722-2101, E-ISSN 2722-4201 \\ Aldi Masyarakat Kreatif \\ Program Studi Ekonomi Manajemen Universitas Pamulang \\ Jurnal LOKABMAS Kreatif Vol.02,No.03.Nov 2021 Hal.39-45 \\ Email:jurnalkreatif.manajemen@gmail.com
}

\title{
MEMBANGUN ORANG-ORANG YANG POSITIF DI DALAM ORGANISASI DI DALAM TEAM MANAJEMEN GEOPARK CILETUH SUKABUMI
}

\author{
Ading Sunarto, Nur Rachmah Wahidah, Kasmad, Lisa Novia \\ Universitas Pamulang \\ Email: dosen02153@unpam.ac.id, dosen02317@unpam.ac.id, \\ dosen00559@unpam.ac.id,dosen02121@unpam.ac.id,
}

\begin{abstract}
Abstrak
Pengabdian kepada Masyarakat ini bertujuan untuk memberikan motivasi dalam membangun lingkungan yang positif di dalam organiasi agar antara staf dapat menjalin kerja sama yang merupakan sinergisitas kekuatan dari beberapa orang dalam mencapai satu tujuan yang diinginkan. Kerjasama akan menyatukan kekuatan ide- ide yang akan mengantarkan pada kesuksesan.Cara-cara lama yang masih mereka gunakan adalah pekerjaan yang dikerjakan tanpa adanya koordinasi dan secara individual, tanpa adanya program yang mereka buat, sehingga antara tidak memiliki rasa tanggung jawab akan sebuah program yang akan dilakukan. Masih terdapatnya senioritas dan masih memandang siapa pimpinan dan siapa bawahan, sehingga antara staff tidak membentuk team yang solid.. Selain itu diharapkan dengan pengabdian kepada masyarakat ini keberadaan perguruan tinggi dapat memberikan kontribusi besar kepada pengembangan dan penerapan keilmuan kepada masyarakat. Metode yang kegiatan yang dilaksanakan adalah kami mendatangi langsung ke lokasi PKM yaitu di Ciletuh Geopark Sukabimi yang beralamat di Ciwaru, Ciemas, Sukabumi, Jawa Barat 43177. Hasil pengabdian kepada masyarakat yang diperoleh yakni bertambahnya dorongan motivasi peserta untuk meningkatkan pelestarian dan meningkatkan mutu objek wisata serta bertambahnya keilmuan peserta didalam manajemen organisasi agar mereka memiliki cara pandang yang baik tentang pentingnya meningkatkan dan membangun motivasi diri untuk belajar lebih baik lagi dan belajar bertanggung jawab pada masa kini sebagai bekal mereka untuk kehidupan di masa yang akan datang. Ilmu yang didapatkan pada Pengabdian Kepada Masyarakat kali ini diharapkan mampu memberikan semangat baru bagi dosen dalam upaya mengembangkan diri memberikan pengarahan, penyampaian materi dan motivasi serta berkontribusi bagi generasi muda baik di dalam lingkungan sekolah, kampus, keluarga dan masyarakat secara luas.
\end{abstract}

\section{Kata Kunci: Manusia Positif, Organisasi, Team Manajemen}

\begin{abstract}
This Community Service aims to provide motivation in building a positive environment within the organization so that staff can work together which is a synergistic strength of several people in achieving a desired goal. Cooperation will unite the power of ideas that will lead to success. The old ways that they still use are work that is done without coordination and individually, without any program they make, so that they do not have a sense of responsibility for a program that they create. will be done. There is still seniority and still looking at who is the leader and who is the subordinate, so that the staff does not form a solid team. In addition, it is hoped that with this community service the existence of universities can make a major contribution to the development and application of science to the community. The method carried out is that we go directly to the PKM location, namely at Ciletuh Geopark Sukabimi which is located at Ciwaru, Ciemas, Sukabumi, West Java 43177. The results of community service obtained are
\end{abstract}


increasing the motivation of participants to improve conservation and improve the quality of tourism objects and increasing knowledge of participants in organizational management so that they have a good perspective on the importance of improving and building self-motivation to study better and learn to be responsible for the present as their provision for life in the future. The knowledge gained in Community Service this time is expected to be able to provide new enthusiasm for lecturers in an effort to develop themselves, provide direction, delivery of material and motivation and contribute to the younger generation both within schools, campuses, families and society at large.

Keywords: Positive People, Organization, Management Team

\section{PENDAHULUAN}

Saat ini banyak sekali destinasi wisata yang di minati oleh masyarakat salah satunya adalah Geopark CIletuh. Ciletuh Geopark Sukabumi adalah tempat Destinasi wisata yang beralamatkan di desa Ciwaru kecamatan ciemas Kabupaten Sukabumi provinsi Jawa Barat negara Indonesia dengan kode pos 43177. dan di dalam geopark ciletuh ada tim manajemennya. Persoalan team manajemen yang dihadapi pada saat ini adalah kurangnya motivasi untuk membangun team yang solid, sehingga antar staf tidak terjalin komunikasi yang baik. Banyak program kerja yang dibuat tanpa adanya koordinasi antara pimpinan dan bawahan. Sehingga banyak kesalah fahaman, yang mengakibatkan kedatangan turis tidak bertambah dan bahkan cenderung berkurang, sarana dan prasarana tidak ada perubahan untuk diperbaiki. . Hal tersebut disebabkan kurangnya motivasi, sehingga teamwork yang dibangunpun kurang solid dalam menjalankan program di dalam manaejemen.

Menurut Dishon and O'Leary (1994) bahwa team work adalah group of two five students who are tied totgether by a common purpose to complete a task and to include every group members. Dalam konteks ini premis mayor dalam suatu tim adalah bahwa setiap orang dalam tim kerja harus berfungsi sebagai pemain yang kooperatif dan produktif untuk menuju tercapainya hasil yang diinginkan. Sedangkan menurut (Tenner dan Detero dalam Hastuti 2009) Teamwork adalah kemampuan individu yang bekerja sama untuk mencapai tujuan yang sama. Orang pada semua tingkat organisasi merupakan faktor yang sangat penting dari suatu organisasi dan keterlibatan mereka secara penuh akan memungkinkan kemampuan mereka digunakan untuk manfaat organisasi (Gaspersz dalam Hastuti: 2009). Dengan demikian, setiap orang dalam struktur organisasi perusahaan dengan tujuan tertentu membutuhkan teamwork yang baik untuk mencapai tujuannya itu. Bukti menunjukkan bahwa tim biasanya bekerja lebih baik daripada individu ketika tugastugas yang dilakukan membutuhkan banyak keterampilan, pendapat, dan pengalaman. Menurut Hughes (2012: 366) teori pembentukan tim harus melewati 4 tahap pembentukan yaitu: tahap forming (pembentukan), tahap storming (goncangan), tahap norming (membangun norma) dan tahap performing (berkinerja). Teori ini tidak dapat diaplikasikan begitu saja kepada masyarakat Indonesia terutama masyarakat suku jawa yang bersifat kolektivistik. Menurut Tjiptono dan Diana (2000:167-168) faktor-faktor penghambat kesuksesan teamwork adalah: Pertama, identitas pribadi anggota tim yaitu tim tidak akan dapat berjalan efektif bila anggotanya belum merasa cocok. Kedua, hubungan antar anggota tim yaitu setiap anggota tim harus saling mengenal dan berhubungan untuk dapat berkerja sama. Dan yang ketiga, identitas dalam organisasi yaitu kecocokan tim dalam organisasi.

Teamwork juga bagaikan sebuah orkestra yang saling bekerja sama menimbulkan suatu musik yang indah. Bila salah seorang pemain salah memainkan alat musiknya maka akan menimbulkan disharmonis. Team work akan berhasil hanya jika mereka dapat melenyapkan 
dan berkonsentrasi pada perbedaan pandangan dan keahlian untuk mengatasi masalah atau tantangan dengan cepat. Berdasarkan penjelasan mengenai teamwork dari berbagai teori di atas, maka juga dapat di ambil sebuah kesimpulan bahwa teamwork adalah kemampuan individu dalam melakukan kerjasama dengan baik untuk mencapai tujuan bersama di dalam tim yang saling percaya dan mendukung serta bertanggungjawab terhadap tugas-tugas yang telah diberikan. Untuk menciptakan teamwork yang solid dibutuhkan pelatihan pembelajaran edutaiment. Pengertian Edutainment adalah suatu proses pembelajaran yang didesain sedemikian rupa, sehingga muatan pendidikan dan hiburan dikombinasikan secara harmonis untuk menciptakan pembelajaran yang menyenangkan. Dalam hal ini, pembelajaran yang menyenangkan biasanya dilakukan dengan humor, permainan (game), bermain peran (role play), dan demonstrasi. Bermain dengan suasana menyenangkan merupakan faktor sangat penting dalam training staff. Bermain dan bersenang-senang merupakan aktivitas yang esensial bagi semua manusia. Dalam bidang psikologi positif, bahwa edutainment adalah suatu cara untuk membuat proses informasi bisa begitu menyenangkan, sehingga para turis dapat dengan mudah menangkap esensi dari informasi itu sendiri.

Adapun tujuan dari PkM (Pengabdian kepada Masyarakat) adalah untuk membangun positive vibes atau aura positif di dalam organisasi terutama pada team manajemen Geopark Ciletuh Sukabumi, kemudian untuk membangun kebiasaan kerja yang terstandarisasi untuk menciptakan kualitas yang baik pada team manajemen Geopark Cieltuh Sukabumi. Secara teoritis PkM ini diharapkan bermanfaat untuk masyarakat terutama team manajemen Geopark Ciletuh Sukabumi, sehingga bekerja di dalam team dapat lebih maksimal lagi. Pengabdian kepada Masyarakat $(\mathrm{PkM})$ ini diharapkan dapat menambah wawasan dan ilmu pengetahuan, secara faktual di lapangan tentang membangun tim yang positif.
Berdasarkan latar belakang tersebut, kami dari Tim Program Pengabdian Masyarakat (PKM) Universitas Pamulang (UNPAM terpanggil untuk ikut serta membantu memecahkan persoalan yang dihadapi oleh Manajemen Geopark Ciletuh dengan judul PKM: "Membangun Orang orang yang positif di dalam organisasi pada team manajemen Geopark Ciletuh Sukabumi”.

\section{RUMUSAN MASALAH}

Berdasarkan latar belakang diatas, tim PkM (Pengabdian kepada Masyarakat) kami merumuskan kegiatan ini yang mendasar yaitu :

1. Bagaimana cara membangun positive vibes atau aura positif di dalam organisasi terutama pada team manajemen Geopark Ciletuh Sukabumi?

2. Bagaimana membangun kebiasaan kerja yang terstandarisasi untuk menciptakan kualitas yang baik pada team manajemen Geopark Ciletuh Sukabumi?

\section{TUJUAN PELAKSANAAN}

Adapun tujuan dari PkM (Pengabdian kepada Masyarakat) adalah sebagai berikut :

1. Untuk membangun positive vibes atau aura positif di dalam organisasi terutama pada team manajemen Geopark Ciletuh Sukabumi .

2. Untuk membangun kebiasaan kerja yang terstandarisasi untuk menciptakan kualitas yang baik pada team manajemen Geopark Cieltuh Sukabumi .

\section{TINJAUAN PUSTAKA}

Berpikir positif adalah aktivitas berpikir yang dilakukan dengan tujuan untuk membangun dan membangkitkan aspek positif pada diri, baik itu yang berupa potensi, semangat, tekad maupun keyakinan diri kita sehingga memunculkan perasaan, perilaku, dan hal yang baik dan telah 
menjadi

sebuah system berpikir yang mengarahkan dan membimbing seseorang untuk meninggalkan hal-hal negative yang bisa melemahkan semangat perubahan dalam jiwanya.

Elfiky (2012) menjelaskan bahwa berpikir positif merupakan sumber kekuatan dan sumber kebebasan. Dikatakan sumber kekuatan karena bisa membantu seseorang memikirkan solusi sampai mendapatkannya sehingga seseorang bertambah mahir, percaya dan kuat. Dikatakan sumber kebebasan karena mampu membebaskan seseorang dari kungkungan pikiran negatif serta pengaruhnya pada fisik. Berpikir positif menurut Andrea juga diartikan sebagai sikap mental yang melibatkan proses memasukkan pikiran-pikiran, kata-kata, dan gambaran- gambaran yang konstruktif bagi perkembangan pikiran. Dengan demikian, pikiran positif akan melahirkan kebahagiaan, sukacita, kesehatan, serta kesuksesan dalam setiap situasi dan tindakan (Andrea, 2011). Hakim (dalam Yuspita, 2007) mengungkapkan di dalam hidup ini setiap orang akan dihadapkan pada suatu aktivitas yang penuh tantangan, banyak orang tidak menyadarinya ketika menghadapi tantangan hidup ini. Ia mengahadapi hambatan berat yang berasal dari dirinya sendiri, seperti adanya pikiranpikiran negatif dalam bentuk kemauan yang lemah, sikap pesimis, ketergantungan pada orang lain, dan bayangan-bayangan takut gagal yang tidak realistis. Maka dengan berpikir positif masalah tersebut dapat diatasi, karena pikiran positif akan mengarahkan seseorang pada sikap opitimis, menyukai tantangan, mencari solusi, dan punya kemauan yang kuat.

Pengertian organisasi adalah sebuah wadah atau tempat berkumpulnya sekelompok orang untuk bekerjasama secara rasional dan sistematis, terkendali, dan terpimpin untuk mencapai suatu tujuan tertentu dengan memanfaatkan sumber daya yang ada. Pada umumnya organisasi akan memanfaatkan berbagai sumber daya tertentu dalam rangka untuk mencapai tujuan, seperti; uang, mesin, metode/ cara, lingkungan, sumber daya manusia, dan sumber daya lainnya, yang dilakukan secara sistematis, rasional, dan terkendali.

Pengertian organisasi dalam dunia bisnis yaitu sekelompok orang atau grup yang berkolaborasi bersama-sama demi mencapai tujuan komersil. Layaknya organisasi non-profit, dalam dunia binis istilah ini juga memiliki struktur yang jelas dan sudah memiliki budaya kerja. Karena itu, beda organisasi akan beda pula struktur dan tujuannya. Pengertian Organisasi Menurut Para Ahli. Beberapa ahli pernah menjelaskan definisi organisasi, diantaranya adalah:

1. Stoner, menurut Stoner pengertian organisasi adalah sebuah pola hubungan-hubungan melalui mana orang-orang di bawah pengarahan atasan untuk mencapai tujuan bersama

2. Stephen P. Robbins, menurut Stephen P. Robbins pengertian organisasi adalah kesatuan (entity) sosial yang dikoordinasikan secara sadar, dengan sebuah batasan yang relatif dapat diidentifikasi, yang bekerja atas dasar yang relatif terus menerus untuk mencapai suatu tujuan bersama atau sekelompok tujuan.

3. James D. Mooney, menurut James D. Mooney pengertian organisasi adalah bentuk setiap perserikatan manusia untuk mewujudkan tujuan bersama.

\section{HASIL DAN PEMBAHASAN}

Keindahan Geopark Ciletuh yang terletak di delapan Desa Kecamatan Ciemas dan Ujung Genteng Kab. Sukabumi . Geopark Ciletuh memiliki luas sekitar 128.000 hektare dan mencakup 74 desa di delapan kecamatan, yakni Kecamatan Cisolok, Kecamatan Cikakak, Kota Pelabuhan Ratu, Kecamatan Simpenan, Kecamatan Waluran, Kecamatan Ciemas, Kecamatan Ciracap, dan Kecamatan Surade. Awalnya, Geopark Ciletuh hanya mencakup tiga kecamatan. Geopark Ciletuh memiliki bentuk menyerupai tapal kuda 
(amphitheater) dengan diameter sekitar 15 kilometer yang menghadap ke Teluk Ciletuh. Dengan area yang berada dalam naungan UNESCO. Begitu luas, jumlah obyek wisata di Geopark Ciletuh pun sangat banyak, mencapai 70 obyek wisata.

Peserta yang hadir sebanyak 25 team Manajemen Geopark Ciletuh Sukabumi, para dosen dan Mahasiswa Universitas Pamulang. Kegiatan dilaksanakan melalui diskusi tanya jawab, dengan cara para narasumber memberikan penyuluhan dan diikuti oleh para peserta yang kumpul di Aula bupati Sukabumi g yang antusias menyimak dengan menggunakan sebuah laptop yang disambungan ke LCD proyektor. Kegiatan berjalan baik dan lancar, banyaknya peserta yang antusias untuk bertanya seputar oraganisasi yang baik dan positif, hal tersebut tentu membuat para nara sumber lebih bersemangat lagi untuk memberikan sosialisasi.

Persoalan team manajemen yang dihadapi pada saat ini adalah kurangnya motivasi untuk membangun team yang solid, sehingga antar staf tidak terjalin komunikasi yang baik. Banyak program kerja yang dibuat tanpa adanya koordinasi antara pimpinan dan bawahan. Sehingga banyak kesalah fahaman, yang mengakibatkan kedatangan turis tidak bertambah dan bahkan cenderung berkurang, sarana dan prasarana tidak ada perubahan untuk diperbaiki. . Hal tersebut disebabkan kurangnya motivasi, sehingga teamwork yang dibangunpun kurang solid dalam menjalankan program di dalam manajemen.

Team work akan berhasil hanya jika mereka dapat melenyapkan kompetisi dan berkonsentrasi pada perbedaan pandangan dan keahlian untuk mengatasi masalah atau tantangan dengan cepat. Berdasarkan penjelasan mengenai teamwork dari berbagai teori di atas, maka juga dapat di ambil sebuah kesimpulan bahwa teamwork adalah kemampuan individu dalam melakukan kerjasama dengan baik untuk mencapai tujuan bersama di dalam tim yang saling percaya dan mendukung serta bertanggungjawab terhadap tugas-tugas yang telah diberikan. Untuk menciptakan teamwork yang solid dibutuhkan pelatihan pembelajaran edutaiment. Pengertian Edutainment adalah suatu proses pembelajaran yang didesain sedemikian rupa, sehingga muatan pendidikan dan hiburan dikombinasikan secara harmonis untuk menciptakan pembelajaran yang menyenangkan. Dalam hal ini, pembelajaran yang menyenangkan biasanya dilakukan dengan humor, permainan (game), bermain peran (role play), dan demonstrasi. Bermain dengan suasana menyenangkan merupakan faktor sangat penting dalam training staff. Bermain dan bersenang-senang merupakan aktivitas yang esensial bagi semua manusia. Dalam bidang psikologi positif, bahwa edutainment adalah suatu cara untuk membuat proses informasi bisa begitu menyenangkan, sehingga para turis dapat dengan mudah menangkap esensi dari informasi itu sendiri.

Melalui kegiatan Pengabdian kepada Masyarakat (PkM) ini di harapkan kedepan kebiasaan kerja yang di ciptakan di lingkungan geopark ciletuh akan lebih baik dan selalu berkepribadian positif dalam melayani turis.

\section{KESIMPULAN DAN SARAN}

\section{Kesimpulan}

Pelaksanaan kegiatan Pengabdian Kepada Masyarakat oleh Lembaga Penelitian dan Pengabdian Masyarakat (LPPM) Universitas Pamulang yang dilakukan oleh dosen-dosen Program Studi Manajemen telah berjalan dengan lancar dan mendapat sambutan positif dan hangat dari tempat pelaksanaan kegiatan PKM di Deopark Ciletuh Sukabumi. Meski pada masa PSBB namun dengan tetap melaksankan protokol sesuai anjuran pemerintah setempat Perserta terlihat antusias mengikuti sosialisasi walau keterbatasan sarana prasana. Penyuluhan tentang Membangun orang orang yang positif di dalam organisasi pada team manajemen Geopark Ciletuh Sukabumi. Harapan kami selaku dosen dengan adanya kegiatan PKM ini dapat menambah ilmu 


\section{Loyalitas Kreativitas Aldi Masyarakat Kreatil}

P-ISSN 2722-2101, E-ISSN 2722-4201

Program Studi Ekonomi Manajemen Universitas Pamulang Jurnal LOKABMAS Kreatif Vol.02,No.03.Nov 2021 Hal.39-45

Email:jurnalkreatif.manajemen@gmail.com bermanfaat dalam hal sikap disiplin dan tanggung jawab.

Dalam laporan kegiatan PKM ini meungkin banyak kekurangan yang ada, untuk itu kami berharap masukan dan kritikan dalam rangka perbaikan untuk kegiatan PKM selanjutnya. Semoga kegiatan PKM ini dapat bermanfaat bagi masyarakat di sekitar Universitas Pamulang dan lainnya.

Akhirnya, kami mengucapkan banyak terimakasih kepada seluruh pihak yang telah mendukung dan berkontribusi dalam kegiatan PKM ini dan kami memohon maaf apabila dalam kegiatan PKM ini banyak ditemukan kekurangan dan kesalahan

\section{Saran}

Adapun beberapa saran untuk team manajemen Geopark Ciletuh Sukabumi dalam membangun orang orang yang positif di dalam berorganisasi adalah sebagai berikut :

1. Bisa membaca situasi yaitu pahami latar belakang dan keadaan

2. Dalam menjalankan tugas, petakan tantangan dan harapan. Apa yang harus dilakukan dan mengapa harus di lakukan

3. Mengambil tindakan yang etis dan sesuai prosedur, membantu tanpa melanggar ketentuan

4. Menjaga reputasi dan kredibilitas organisasi dengan pelayanan yang memuaskan stakeholder

\section{FOTO KEGIATAN}

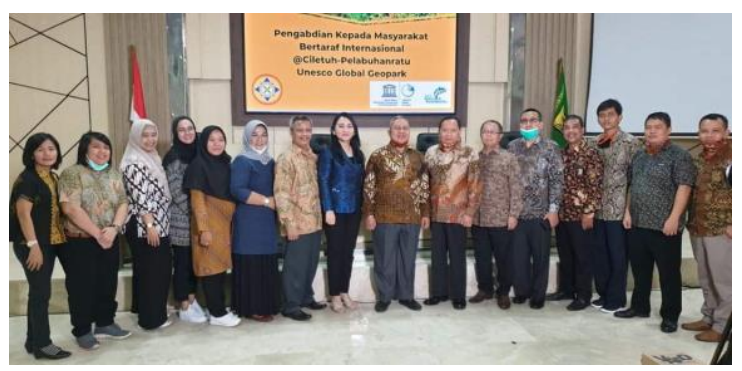

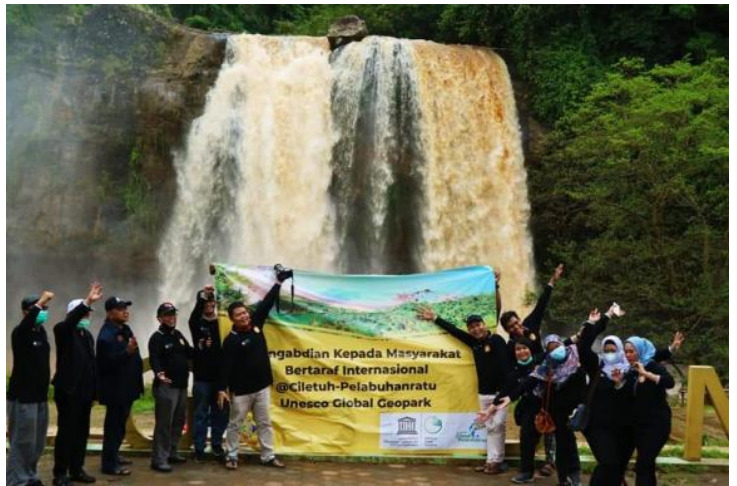
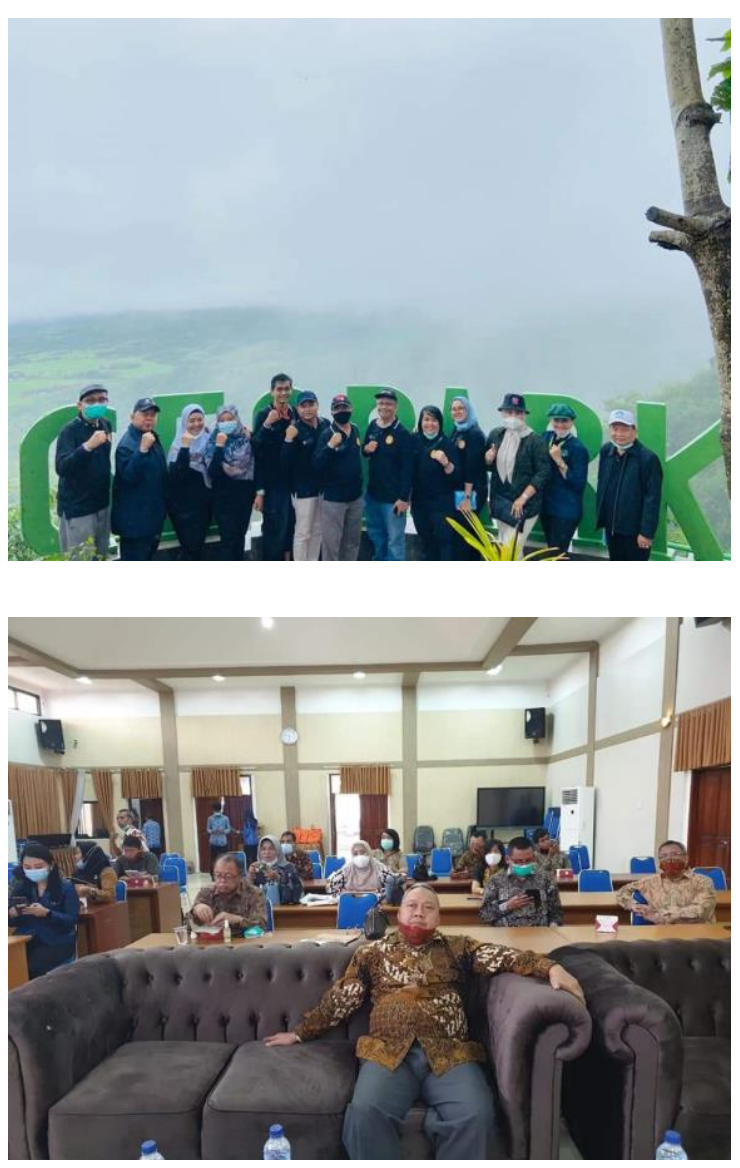

\section{DAFTAR PUSTAKA}

Andrea, Michael. (2011). Kekuatan Super Dahsyat Berpikir Positif.Yogyakarta: Pinang Merah.

Ayu, Dyah dan Rini Hastuti. 2009. "Persepsi WP: "Dampak

PertentanganDiametral Pada Tax Evasion WP Dalam Aspek Kemungkinan Terdeteksinya Kecurangan, Keadilan, Ketepatan 
Pengalokasian, Teknologi Sistem Perpajakan, dan

Dishon, D. \& O’Leary, W.P. (1994). A Guidebook for cooperative Learning: A Technique for Creating More Effective Schools. Holmes Beach, FL: Learning Publication, ${ }^{\text {nd }}$ Edition.

Elburdah, R. P., Pasaribu, V. L. D., Rahayu, S., Septiani, F., \& Metarini, R. R. A. (2021). MOMPRENEUR PENOPANG PEREKONOMIAN KELUARGA DI MASA PANDEMI COVID-19 DENGAN BISNIS ONLINE PADA KELURAHAN PONDOK BENDA. Abdi Laksana: Jurnal Pengabdian Kepada Masyarakat, 2(1), 75-82

Hakim, A. "Analisis pengaruh motivasi, komitmen organisasi, dan iklim organisasi terhadap kinerja pegawai, studi pada dinas perhubungan dan telekomunikasi propinsi jawa tengah, JRBI Vol.2, No.2, Juli 2006 : 165180."

Hughes, R. L., Ginnet, R. C., and Curphy, G. J.2012.Leadership:Memperkaya Pelajaran dari Pengalaman.Edisi Ketujuh.Jakarta:Salemba Humanika

Ibrahim Elfiky, Terapi Berpikir Positif, Gita Print, Bandung, 2012.

Pasaribu, V. L. D., Agrasadya, A., Shabrina, N., \& Krisnaldy, K. (2020). Menjadi Enterpreneur Muda Yang Memiliki Jiwa Leadership Untuk Menghadapi Masa Depan. Abdi Laksana: Jurnal Pengabdian Kepada Masyarakat, 1(1).

Pasaribu, V. L. D., Susanti, F., \& Hartuti, E. T. K. (2019). Memotivasi Siswa dan Siswi SMK Letris Indonesia di Dalam Menentukan Pilihan Untuk Melanjutkan Pendidikan Atau Bekerja Setelah Lulus Sekolah. Jurnal Pengabdian Dharma Laksana, 1(2),
161-172.

Pasaribu, V. L. D., Sulaiman, S., Sutiman, S., Thaharudin, T., \& Purnomo, B. Y. (2020). Pengenalan Letak Posyandu Terdekat Dikelurahan Pisangan Dengan Manajemen Pemasaran Revolusi 4.0 Untuk Meningkatkan Pengetahuan Masyarakat Letak Dan Fungsi Posyandu Terdekat Pada Kelurahan Pisangan. Dedikasi Pkm, l(1), 105-110.

Pasaribu, V. L. D., Oktrima, B., Prabowo, B., Arianto, N., \& Haryoko, U. B. (2020). Progam Pendampingan Dan Penyelenggaraan Pendidikan Anak Pada Usia Dini Terhadap Prestasi Belajar Dilingkungan Rt 020 Rw 009. Kel Giri Peni. Kec Wates. Yogyakarta. Jurnal Lokabmas Kreatif, 1(1), 71-75.

Pasaribu, V. L. D., Jannah, M., Fazar, M., Putra, S. P., Monalisa, M., \& Sofa, M. (2021). MENINGKATKAN

PRODUKTIVITAS

USAHA

DIMASA PANDEMI PADA IBU PKK RT 004/003 KELURAHAN SAWAH BARU CIPUTAT, TANGERANG SELATAN. Abdi Laksana: Jurnal Pengabdian Kepada Masyarakat, 2(2), 295-301.

Pasaribu, V. L. D., Yuniati, H. L., Pranata, R., Sembayu, R., Purba, S. M., \& Nurbayani, T. T. A. (2021). MANAJEMEN KEUANGAN UNTUK MENGHADAPI DAN BERTAHAN DI ERA COVID 19. Jurnal Abdimas Tri Dharma Manajemen, 2(2), 12-18.

Pasaribu, V. L. D., Dwiyatni, A., Sabina, C., Ridwan, M., Gunawan, D. D., \& Noviani, B. C. (2021). EVALUASI PENERAPAN 3M DIMASA PANDEMIC COVID 19. Jurnal Abdimas Tri Dharma Manajemen, 2(2), 54-60.

Pasaribu, V. L. D., Syafei, A. N., Farhan, A., Aufaizah, A., Irani, C., \& Firtiayani, S. R. (2021). PENGARUH DISPLIN PROTOKOL KESEHATAN TERHADAP PENCEGAHAN PENULARAN VIRUS COVID19. Jurnal Abdimas Tri Dharma 


\section{Loyalitas Kreativitas Aldi Masyarakat Kreatif}

Manajemen, 2(2), 91-98.

Pasaribu, V. L. D., Septiani, F., Rahayu, S., Lismiatun, L., Arief, M., Juanda, A., ... \& Rahim, R. (2021). Forecast Analysis of Gross Regional Domestic Product based on the Linear Regression Algorithm Technique.

Pasaribu, V. L. D., Priadi, A., Anismadiyah, V., Rahayu, S., \& Maduningtias, L. (2021). PENYULUHAN KREATIF DAN INOVATIF MENINGKATKAN MUTU PRODUKSI UMKM DI DESA BELEGA KABUPATEN GIANYAR. Pro Bono Jurnal Pengabdian Kepada Masyarakat, l(02).

Pasaribu, V. L. D. (2021). PELATIHAN BERBASIS ONLINE DI ERA COVID-19. Jurnal Abdimas Tri Dharma Manajemen, 2(3), 26-32.

Pasaribu, V. L. D., \& Setyowati, R. (2021). ADAPTASI KEHIDUPAN NEW

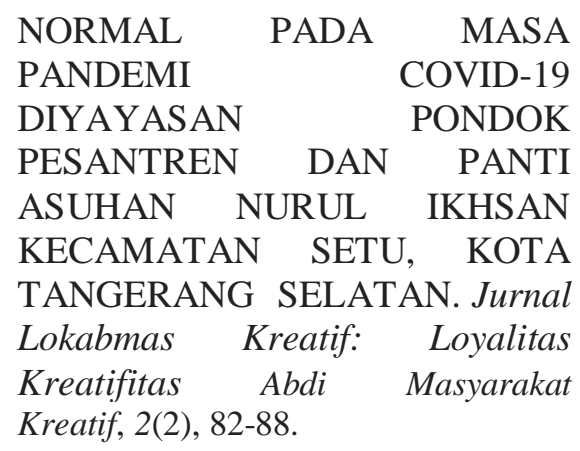

Priadi, A., Pasaribu, V. L. D., Virby, S., Sairin, S., \& Wardani, W. G. (2020).
Penguatan Ekonomi Kreatif Berbasis

Sumber Daya Desa Dikelurahan

Rempoa. Abdi Laksana: Jurnal

Pengabdian Kepada

Masyarakat, 1(3), 356-35

Sunarto, A. (2020). Pengembangan Sumber Daya Manusia dengan Berbasis Inovasi Untuk Menghadapi Revolusi Industri 4.0. Jurnal Ilmiah MEA (Manajemen, Ekonomi, dan Akuntansi). 4 (2).

Sunarto, A. (2020). Kinerja Karyawan Berbasis Kepemimpinan Dan Motivasi Pada PT. Duta Jaya Putra Persada Mining. JENIUS (Jurnal Ilmiah Manajemen Sumber Daya Manusia), 3(3), 246-257.

Sunarto, A. (2021). KINERJA PEGAWAI BERBASIS DISIPLIN DAN LINGKUNGAN KERJA (Studi Pada Kantor Kecamatan Pondok Aren Kota Tangerang Selatan). Jurnal Visionida, 7(1), 1-13.

Sunarto, A. (2021). PENGARUH KOMUNIKASI DAN GAYA KEPEMIMPINAN TERHADAP KINERJA PEGAWAI PADA PT. VISIONET DATA INTERNASIONAL CABANG KARAWACI. Jurnal Semarak, 4(2), 105-118.

Tjiptono, Fandy dan Anastasia Diana, Total Quality Manajemen, Edisi Ketiga, Penerbit Andi, Jogjakarta, 2000 